DOI: $10.36910 / 6775-2524-0560-2020-40-14$

УДК: 620.179 .1

Топчій Наталія Володимирівна, науковий співробітник

https://orcid.org/0000-0003-2924-6365

Шорнікова Світлана Василівна, науковий співробітник

https://orcid.org/0000-0002-9038-2457

Альховик Ольга Василівна, науковий співробітник

https://orcid.org/0000-0002-7335-4147

Український науково-дослідний інститут спеціальної техніки та судових експертиз Служби безпеки України

\title{
ІННОВАЦІЙНІ МЕХАНІЗМИ НЕРУЙНІВНОГО КОНТРОЛЮ В УМОВАХ ВИРОБНИЦТВА
}

Топчій Н.В., Шорнікова С.В., Альховик О.В. Інноваційні механізми неруйнівного контролю в умовах виробництва. Наведено інноваційні механізми неруйнівного контролю в умовах виробництва. Розкрито напрями за якими розподіляються засоби неруйнівного контролю, визначено, що основа вибору методу і приладу неруйнівного контролю для вирішення завдань дефектоскопії, товщинометрії, структуроскопії і технічного діагностування залежить від параметрів контрольованого об'єкта і умов його обстеження. Зазначається, що виявити поверхневі дефекти, як на зовнішніх поверхнях, так і у внутрішніх порожнинах виробів і виміряти їх параметри дозволяють візуальний і вимірювальний методи. У статті описано особливості радіаційного методу контролю, акустичного (ультразвукового) методу, магнітопорошкового або магнітолюмінесцентного методу, вихрострумового методу та теплового. Також, у рамках роботи наведено інноваційні механізми неруйнівного контролю в умовах виробництва у різних галузях: будівельної, аерокосмічної, мікроелектроніки, атомно-оптичної мікроскопії біологічних об'єктів. Для машинобудівних підприємств розкрито принципи перспективної розробки нових методів і засобів контролю. Окреслено технологію CALS, яка передбачає подання в електронній формі всіх даних і документів, що використовуються для опису виробу або того, як він виробляється і експлуатується, для інформаційної підтримки різних процедур, використовуваних протягом усього життєвого циклу виробу. Визначено місце персонального комп'ютера у системі CALS технологій, зазначено, що в автоматизованих засобах персонального комп'ютера всі процеси контролю і розсортування виробів виконуються автоматично без участі оператора, а до їх складу входять засоби переміщення контрольованих об'єктів, пристрої стабілізації їх положення в процесі контролю, системи механічного сканування перетворювачем поверхні виробу, сполучні елементи електричних виконавчих пристроїв, системи супроводу проконтрольованої продукції, блокувальні пристрої та інше.

Ключові слова: неруйнівний контроль, інновації, механізм, контроль якості, властивості, матеріали, конструкції, граничні значення, автоматизація.

Топчий Н. В., Шорникова С. В., Альховик О. В. Инновационные механизмы неразрушающего контроля в условиях производства. Приведены инновационные механизмы неразрушающего контроля в условиях производства. Раскрыто направления по которым распределяются средства неразрушающего контроля, определено, что основа выбора метода и прибора неразрушающего контроля для решения задач дефектоскопии, толщинометрии, структуроскопии и технического диагностирования зависит от параметров контролируемого объекта и условий его обследования. Отмечается, что выявить поверхностные дефекты, как на внешних поверхностях, так и во внутренних полостях изделий и измерить их параметры позволяют визуальный и измерительный методы. В статье описаны особенности радиационного метода контроля, акустического (ультразвукового) метода, магнитопорошкового или магнитолюминесцентного метода, вихретокового метода и теплового. Также, в рамках работы приведены инновационные механизмы неразрушающего контроля в условиях производства в различных отраслях: строительной, аэрокосмической, микроэлектроники, атомно-оптической микроскопии биологических объектов. Для машиностроительных предприятий раскрыты принципы перспективной разработки новых методов и средств контроля. Определены технологию CALS, которая предусматривает в электронной форме всех данных и документов, используемых для описания изделия или того, как он производится и эксплуатируется, для информационной поддержки различных процедур, используемых на протяжении всего жизненного цикла изделия. Определено место персонального компьютера в системе CALS технологий, указано, что в автоматизированных средствах персонального компьютера все процессы контроля и рассортировке изделий выполняются автоматически без участия оператора, а в их состав входят средства перемещения контролируемых объектов, устройства стабилизации их положения в процессе контроля, системы механического сканирования преобразователем поверхности изделия, соединительные элементы электрических исполнительных устройств, системы сопровождения проконтролированной продукции, блокировочные устройства и прочее.

Ключевые слова: неразрушающий контроль, инновации, механизм, контроль качества, свойства, материалы, конструкции, предельные значения, автоматизация.

Topchii Natalia, Shornikova Svitlana, Alkhovyk Olga. Innovative mechanisms of non-destructive control in the production conditions. Innovative mechanisms of non-destructive testing in the conditions of production are given. The directions in which the means of non-destructive testing are distributed are revealed, it is determined that the basis for choosing the method and device of non-destructive testing to solve problems of defectoscopy, thickness measurement, structuroscopy and technical diagnosis depends on the parameters of the controlled object and its inspection conditions. It is noted that to detect surface defects, both on the outer surfaces and in the internal cavities of the products and to measure their parameters allow visual and measuring methods. The article describes the features of the radiation control method, acoustic (ultrasonic) method, magnetic powder or magnetoluminescent method, eddy current method and thermal. Also, in the framework of the work innovative mechanisms of non-destructive testing in the conditions of production in various branches are given: construction, aerospace, microelectronics, atomic-optical microscopy of 
biological objects. The principles of perspective development of new methods and means of control are revealed for machine-building enterprises. CALS technology is outlined, which provides electronic submission of all data and documents used to describe the product or how it is manufactured and operated, to provide information support for the various procedures used throughout the product life cycle. The place of the personal computer in the CALS system of technologies is defined, it is noted that in the automated means of the personal computer all processes of control and sorting of products are carried out automatically without participation of the operator, and their structure includes means of movement of the controlled objects. control process, systems of mechanical scanning by the converter of a surface of a product, connecting elements of electric executive devices, systems of support of the controlled production, blocking devices and other.

Key words: non-destructive testing, innovations, mechanism, quality control, properties, materials, constructions, limit values, automation.

Вступ та постановка проблеми дослідження. Неруйнівний контроль у виробництві надає можливість реалізовувати безперервний контроль - від операції до операції, також дозволяє стежити за правильністю зміни властивостей заготовок, і деталей, і подальшим складанням виробів; а надалі перевірити якість готового виробу [1].

Засоби неруйнівного контролю розподіляються за такими напрямами:

- дефектоскопія (виявлення дефектів типу порушень суцільності-тріщин - раковин, розшарувань і т. д.);

- $\quad$ контроль геометричних характеристик (зовнішніх і внутрішніх діаметрів; товщин стінок, покриттів і шарів; ступеня зносу; ширини і довжини виробів і т. д.);

- визначення фізико-механічних і фізико-хімічних характеристик (електричних, магнітних і структурних параметрів, відхилень від заданого хімічного складу, твердості, пластичності, якості зміцнених шарів, змісту і розподілу феритної фази і т. п.);

- $\quad$ технічне діагностування (визначення технічного стану об'єкта в період експлуатації).

Вибір методу і приладу неруйнівного контролю для вирішення завдань дефектоскопії, товщинометрії, структуроскопії і технічного діагностування залежить від параметрів контроль ованого об'єкта і умов його обстеження.

Дефекти типу порушень суцільності $є$ наслідком недосконалості структури матеріалів і виникають на різних стадіях технологічного процесу і в процесі експлуатації [2].

Завданнями, що виникають 3 вимог CALS-технологій, є автоматизація розробки технологій контролю, розшифровки його результатів і архівування. До складу засобів представлення інформації входять пристрої, призначені для перетворення отриманих від вхідних перетворювачів електричних сигналів в динамічні, або статичні зображення досліджуваних випромінювань або полів. Ці засоби кількісно характеризують дефекти типу порушень суцільності, відхилення розмірів, зміни фізикомеханічних властивостей, сигналізують про можливість виникнення аварійної ситуації або досягнення обраних рівнів розбракування виробів. Там, де інформація по контрольованому об'єкті видається приладом у вигляді електричних сигналів (ультразвукова дефектоскопія, вихрострумова дефектоскопія та ін.), завдання розшифровки та архівування результатів контролю вирішуються в електронній формі. У той же час такі методи, як радіографічний, рентгенотелевізійний, магнітопорошковий, капілярний і ін., результати яких оператор оцінює візуально по зображеннях дефектів, автоматизовані в повному обсязі. Створення автоматизованих систем обробки та аналізу зображень на рівні можливостей людського зору для зазначених методів $\epsilon$ актуальним завданням.

Аналіз останніх досліджень і публікацій. В умовах сьогодення, наукові дослідження у сфері неруйнівного контролю в умовах виробництва $є$ доволі масштабними.

Методи та принципи напружено-деформованого стану металевих конструкцій розкривають В.В. Божак, Н. Я. Габльовська, М.А. Кононенко [3]. Авторами розкрито ряд методів контролю, які засновані на оцінюванні інформативних параметрів, встановлені граничні значення котрих однозначно свідчать про напружено-деформований стан конструкції в цілому.

А. В. Наконечна [4] наводить ультразвуковий метод контролю якості зварних з’єднань. У роботі розкриваються параметри які оцінюють виявлений дефект при ультразвуковому контролі.

О.В. Радько, О.І. Кремешний, А.К. Скуратовський, Г.Г. Голембієвський [5] розкривають властивості композиційних матеріалів, методи контролю їх стану, а також пропонують вимоги до нових (модернізованих) систем діагностування та найбільш ефективні методи контролю.

У [6] проведено аналіз методів неруйнівного контролю, їх особливостей, параметрів та необхідного обладнання. Запропоновано оптимальне поєднання різних за своєю природою методів неруйнівного контролю. 
Однак незважаючи на масштабність наукових досліджень, питання визначення інноваційних механізмів неруйнівного контролю в умовах виробництва залишається відкритим та потребує детального опрацювання.

Постановка завдання. У статті необхідно розкрити інноваційні механізми неруйнівного контролю в умовах виробництва.

Виклад основного матеріалу дослідження. У сучасному машинобудуванні використовують практично всі існуючі методи неруйнівного контролю (НК).

Візуальний і вимірювальний методи, в тому числі з використанням жорстких і гнучких відеоендоскопів, дозволяють виявити поверхневі дефекти, як на зовнішніх поверхнях, так і у внутрішніх порожнинах виробів і виміряти їх параметри [7].

Радіаційні методи контролю 3 використанням випромінювання рентгенівських апаратів i радіоактивних джерел застосовують для виявлення внутрішніх дефектів в деталях, вузлах, виробах, у зварних i паяних з'єднаннях шляхом їх просвічування на рентгенівську плівку або на інші перетворювачі випромінювання; для вимірювання товщини деталей і покриттів на них, а також для контролю механічних напруг (рентгенівська дифрактометрія).

Радіаційні методи контролю За допомогою акустичних (ультразвукових) методів контролюють якість листових матеріалів та інших заготовок, зварних, паяних і клеєних з'єднань, деякі фізикомеханічні властивості, використовуючи закони поширення в речовині пружних коливань (лунаімпульсний метод, імпедансно-акустичний метод, метод емісії хвиль напруги - акустичної емісії та ін.) [8].

Поверхневі дефекти типу волосовин, тріщин, непроварів у виробах з феромагнітних металів виявляють в основному магнітопорошковим або магнітолюмінесцентним методами, використовуючи спеціальні порошки, суспензії і пасти, які наносять на попередньо намагнічені об'єкти контролю, і потім розглядаючи картину їх розподілу на поверхні.

Вихрострумові методи використовують для визначення властивостей металу, однозначно пов'язаних з електропровідністю і магнітною проникністю, для виявлення дефектів, для вимірювання діаметра прутків, товщинометрії труб і листів, для вимірювання товщини i визначення якості покриттів. Вихрові струми в металі можна порушувати синусоїдальним і несинусоїдальним електромагнітним полем, імпульсним полем, а також полем змінної частоти. У цих випадках вимірюють частотний спектр, крутизну фронтів, тривалість імпульсів і інші параметри електричних сигналів.

Для виявлення тріщин, раковин, окисних плівок, непроварів, непропаїв та інших дефектів, що мають вихід на поверхню, застосовують також капілярні методи (люмінесцентний, кольоровий та ін.). При проведенні контролю капілярними методами на поверхню контрольованого об'єкта наносять так звані індикаторні пенетранти, здатні проникати в капілярні отвори і мають характерний колірний тон або (i) люмінесціюючі під дією ультрафіолетового випромінювання [9]. Після деякої витримки залишки рідини змивають з неушкодженої поверхні виробу, поверхневі ж дефекти при цьому залишаються заповненими нею.

Теплові методи, що використовують теплові властивості контрольованого виробу, засновані на реєстрації інфрачервоного випромінювання, що виходить з поверхні нагрітого тіла, або його теплового поля приймачами різного типу. Основна область застосування цих методів-контроль паяних і клеєних з'єднань, дефектоскопія виробів 3 композиційних та інших неметалевих матеріалів, виявлення води в конструкціях.

Працездатність і надійність виробів і окремих вузлів крім їх міцності забезпечуються герметичністю оболонок і перегородок. Порушення герметичності можуть викликати так звані течіканали або пористі ділянки. Для виявлення і при необхідності вимірювання величини течі застосовують методи течі пошуку (методи контролю герметичності). Всі методи контролю герметичності засновані на проникненні через ці дефекти тих чи інших речовин, в т.ч. газів. Серед них виділяють наступні методи:

- гідравлічний,

- гасовий,

- люмінесцентний,

- газоаналітичний,

- бульбашковий,

- хімічний,

- манометричний,

( ) Топчій Н.В., Шорнікова С.В., Альховик О.В. 
- галогенний,

- мас-спектрометричний,

- радіоактивний та інші.

До методів НК, що не вимагає сканування контрольованих об'єктів, відносяться ультразвукова голографія і голографічна інтерферометрія [10]. Можливість реалізації голографії в ультразвуці базується на властивості когерентності ультразвукових коливань, одержуваних за допомогою звичайних ультразвукових випромінювачів. Оскільки ці коливання легко проникають в оптично непрозорі середовища, є можливість отримувати зображення внутрішньої структури об'єктів, в тому числі зображення дефектів. Метод голографічної інтерферометрії заснований на тому, що відновлене 3 голограми зображення повністю збігається з реальним об'єктом. Однак при наявності будь-яких змін реального об'єкта (наприклад, деформації, зміщення, зміни коефіцієнта заломлення або відображення) на зображенні з'являться інтерференційні смуги, однозначно пов'язані зі змінами в об'єкті і дефектами в ньому.

Для виробів машинобудування, що відрізняються великою різноманітністю застосовуваних в них матеріалів з різними фізико-механічними властивостями, методами і технологічними процесами ïх виготовлення необхідно застосування комплексу взаємодоповнюючих методів і засобів НК.

Tехнологія CALS передбачає подання в електронній формі всіх даних і документів, які використовуються для опису виробу або того, як він виробляється і експлуатується, для інформаційної підтримки різних процедур, використовуваних протягом усього життєвого циклу виробу (включаючи проектування, випробування, виробництво, експлуатацію та утилізацію).

Для того, щоб отримувати інформацію про якість контрольованих об'єктів в електронній формі, потрібно перш за все вирішити питання автоматизації. В автоматизованих засобах ПК всі процеси контролю і розсортування виробів виконуються автоматично без участі оператора [11]. До їх складу входять засоби переміщення контрольованих об'єктів, пристрої стабілізації їх положення в процесі контролю, системи механічного сканування перетворювачем (ультразвуковим, вихрострумовим і ін.) поверхні виробу, сполучні елементи електричних виконавчих пристроїв, системи супроводу проконтрольованої продукції, блокувальні пристрої і т. д.

Як правило, вартість і обсяг робіт зі створення автоматизованих засобів ПК значно перевищують витрати на приладову частину. Робота всіх вхідних в них пристроїв повинна бути узгоджена 3 роботою основного технологічного обладнання. Процес розробки і проектування автоматизованих засобів ПК не повинен віддалятися в часі від процесу розробки основного обладнання для виробництва.

Особливу складність представляють системи сканування, що застосовуються в машинобудуванні там, де неможливе розбирання конструкцій і утруднений підхід до контрольованих поверхонь складної конфігурації. У процесі сканування повинен підтримуватися постійний зазор між перетворювачем, джерелом поля і контрольованим виробом. Рух перетворювача і контрольованого виробу відносно один одного може бути поступальним, обертальним, складним зворотнопоступальним і т.п. системи сканування вимагають високої точності виготовлення. Масове виробництво промислових роботів і маніпуляторів дозволило створити на цій основі різноманітні технологічні комплекси НК. В основу їх створення покладена:

- сукупність приладів НК, які серійно випускаються, що мають вихід на комп'ютер;

- $\quad$ промислових роботів, що виконують функції переміщення датчика приладу щодо об'єкта контролю;

- програм розбракування виробів, а також спеціалізованих пристроїв зв'язку приладу, робота і об'єкта контролю між собою.

В останні роки досягнутий істотний прогрес в обчислювальній промисловій рентгенівській томографії (отримання пошарових зображень контрольованих об'єктів), де ці зображення спочатку існують в електронній формі, і в автоматичній розшифровці рентгенівських знімків. В принципі, ця технологія застосовна для всіх випадків, коли оператор був змушений візуально оцінювати зображення контрольованих об'єктів. Технологія автоматичної розшифровки передбачає наступне:

- $\quad$ введення зображення і супровідної інформації в комп'ютер;

- $\quad$ попередній аналіз зображення, забезпечення придатності до подальшої комп'ютерної обробки за спеціальними програмами;

- $\quad$ пошук і виділення контурів дефектів, їх ідентифікація, визначення геометричних характеристик за допомогою спеціальних програм; 
- $\quad$ автоматичне отримання висновків щодо дефектності контрольованих об'єктів;

- статистична обробка одержуваних результатів;

- $\quad$ занесення результатів контролю в архів.

Кожен новий виріб в умовах сучасного виробництва вимагає використання як традиційних, так i принципово нових матеріалів і конструкцій. У зв'язку 3 цим виникає необхідність не тільки використовувати існуючі, а й створювати нові методи і засоби їх якості. Найбільш складні нові проблеми зазвичай виникають за такими елементами цих виробів:

- $\quad$ теплозахисні матеріали;

- жароміцні матеріали;

- композиційні та інші неметалеві матеріали;

- металоконструкції з нових матеріалів та їх нероз'ємні з'єднання;

- $\quad$ агрегати з неметалевих матеріалів і їх нероз'ємні з'єднання.

В основі інноваційної стратегії подальшого розвитку нових методів і засобів неруйнівного контролю та технічної діагностики лежить, перш за все, розвиток найбільш перспективних напрямків наукових досліджень, націлених на вирішення практичних завдань з урахуванням їх затребуваності різними галузями народного господарства. Перерахуємо ряд таких проблем. Для машинобудівних підприємств перспективна розробка нових методів і засобів контролю:

- дефектів суцільності лиття i несучих літозварних металоконструкцій (в т.ч. великовантажних автомобілів). Перспективно як розвиток акустичних методів і засобів контролю, так i розробка вітчизняного промислового рентгенівського томографа для тривимірної візуалізації виливків, дефектоскопії і розмірометрії складнопрофільованих виробів;

- дефектів зварних з'єднань, як складних по геометрії (фланці картера заднього моста автомобілів, рамні конструкції кузовів дорожніх машин і т. д.), так і виконаних спеціальними способами зварювання (дифузійним, електрошлаковим, електронно-променевим та ін.);

високо-міцний і ін.); структури чавунів в умовах виробництва з метою їх розбракування по марках (сірий,

- якості зчеплення різнорідних матеріалів (наприклад, дефектів наплавок бабітових підшипників та ін.);

- $\quad$ глибини і твердості поверхнево зміцнених шарів (після гарт, цементації та інших видів хіміко-термічної обробки);

- $\quad$ внутрішніх механічних напруг, в т. ч. засобів контролю затягування різьбових з'єднань, на базі методів акустичної тензометрії;

- $\quad$ деградації фізико-механічних властивостей металів на базі контактно-динамічних та інших методів.

Для будівельної галузі, де в найближчі роки прогнозується висока інвестиційна активність:

- $\quad$ розвиток принципів, математичних алгоритмів, програмного забезпечення, розробка датчиків, засобів передачі, обробки і відображення багатосенсорної інформації для систем моніторингу технічного стану несучих будівельних конструкцій висотних і великопролітних будівель і споруд;

- $\quad$ розвиток методу динамічного індентування відповідно до контролю тріщиностійкості і ударної в'язкості будівельних матеріалів (бетонів, асфальтобетонів та ін.).

Будуть встановлені закономірності тріщиноутворення у конструкційних сталях при їх локальному динамічному деформуванні жорсткими інденторами, розроблені обчислювальні методики оцінки характеристик руйнування матеріалів, засновані на аналізі зміни пружних деформацій при мікроударному деформуванні, а також розроблені установки для контролю тріщиностійкості будівельних матеріалів.

Для атомно-оптичної мікроскопії біологічних об'єктів: розробка методик моделювання відеозображень 3 виходів оптичних і атомно-силових мікроскопів 3 метою діагностики нових матеріалів і біологічних об'єктів, алгоритмів виявлення і фільтрації об'єктів, оцінки їх параметрів, побудови траєкторій виділених об'єктів з оцінкою параметрів їх руху, класифікації об'єктів за заданими ознаками, пакету прикладних програм з автоматичної обробки відеозображень, що реалізують отримані алгоритми.

Для мікроелектроніки: створення скануючого мікрохвильового мікроскопа для локального контролю електрофізичних властивостей напівпровідникових матеріалів інтегральних мікросхем, що поєднує функції як атомно-силової, так і НВЧ-мікроскопії.

Для аерокосмічної галузі:

() Топчій Н.В., Шорнікова С.В., Альховик О.В. 
- $\quad$ розробка електронного пондеромоторного товщиноміра захисних нікелевих покриттів у важкодоступних місцях турбінних лопаток;

- $\quad$ розробка термоелектричного товщиноміра захисних нікелевих покриттів на підкладках 3 нержавіючих сталей феритного класу;

- розробка апаратури для контактно-динамічного контролю комплексу фізикомеханічних властивостей спеціальних матеріалів (фторопластів, вуглепластиків та ін.).

Висновки. У ході дослідження визначено інноваційні механізми неруйнівного контролю в умовах виробництва у різних галузях. Економічний ефект від використання розглянутих методів, приладів і технологій неруйнівного контролю і технічної діагностики, буде досягнутий за рахунок: підвищення якості конкурентоспроможності отриманої продукції; імпортозаміщення; вирішення проблем енерго- та ресурсозбереження; запобігання можливим аваріям; обгрунтованого збільшення терміну експлуатації промислових об'єктів; приладів і технологій.

\section{Список бібліографічного опису}

1. Мягкий, О.В. (2018). Підвищення завадостійкості теплової дефектоскопії багатошарових конструкцій та трубопроводів : дис. ... канд. техн. наук : 05.11.13; Міністерство освіти і науки України Національний технічний університет «Харківський політехнічний інститут», МОН України. Харків, 129 с.

2. Vavilov, V., Nesteruk, D., \& Khorev, V. (2012). Ultrasonic and inductive IR thermographic procedures as newly-emerged techniques in thermal NDT. Annual J. Electron. Sofia, Bulgaria, 6(2), 102-109.

3. Божак, В.В., Габльовська, Н.Я., Кононенко, М.А. (2019). Аналіз методів контролю напружено деформованого стану металевих конструкцій. Методи та засоби неруйнівного контролю промислового обладнання: матеріали 7-ої науковопрактичної конференції (м. Івано-Франківськ 19-20 листопада 2019 р.). Івано-Франківськ: ІІТ, ІФНТУНГ, 23-25.

4. Наконечна, А. В. (2019). Ультразвуковий контроль якості зварних з'єднань Методи та засоби неруйнівного контролю промислового обладнання: матеріали 7-ої науково-практичної конференції (м. Івано-Франківськ 19-20 листопада 2019 р.). Івано-Франківськ: ІІТ, ІФНТУНГ, 87-88.

5. Радько, О.В., Кремешний, О.І., Скуратовський, А.К., Голембієвський, Г.Г. (2013). Методи неруйнівного контролю конструкцій із композиційних матеріалів. Системи озброєння і військова техніка, 3(35), 111.

6. Запорожець, А. О., Свердлова, А. Д. (2017). Аналіз методів діагностування теплоенергетичних об'єктів. Наукоємні технології, 3(35), 259-265.

7. Дейнека, Р. (2017). Магнітокондуктивний спосіб дефектоскопії феромагнітних матеріалів. Вісник Національного університету «Львівська політехніка». Серія: Оптимізачія виробничих процесів і технічний контроль у машинобудуванні та приладобудуванні. Львів: Видавництво Львівської політехніки, 867, 60-63.

8. Chernogor, L. F., Lazorenko, O. V., \& Potapov, A. A. (2012, September). Wavelet analysis of multi-fractal ultra-wideband processes in problems of geospace physics. In 2012 6th International Conference on Ultrawideband and Ultrashort Impulse Signals (pp. 249-251). IEEE.

9. Себко, В. В., \& Здоренко, В. Г. (2019). Реалізація вихорострумового методу контролю на основі визначення компонентів різницевого сигналу трипараметрового перетворювача 3 трубчастим виробом. Вісник Київського національного університету технологій та дизайну. Серія: Технічні науки, (1), 26-35.

10. Голик, О. В., Щебенюк Л. А. (2017). Статистичні аспекти неруйнівного контролю дефектності поліімідної емальізоляції в умовах виробництва. Електротехніка і електромеханіка, (1), 47-53.

11. Хорло, Н. Ф. (2019). Аккредитация организаций, выполняющих неразрушающий контроль, как необходимое условие доступа предприятий Украины к международным рынкам промышленных товаров и услуг. Механіка та махинобудування, 1, 171-175.

\section{References}

1. Myahkyy, O.V. (2018). Increasing noise immunity of thermal flaw detection of multilayer structures and pipelines: dis.... cand. tech. Science: 05.11.13; Ministry of Education and Science of Ukraine National Technical University "Kharkiv Polytechnic Institute", Ministry of Education and Science of Ukraine. Kharkiv, 129 p.

2. Vavilov, V., Nesteruk, D., \& Khorev, V. (2012). Ultrasonic and inductive IR thermographic procedures as newly-emerged techniques in thermal NDT. Annual J. Electron. Sofia, Bulgaria, 6(2), 102-109.

3. Bozhak, V.V., Gablyovskaya, N.Ya., Kononenko, M.A. (2019). Analysis of methods for controlling the stress-strain state of metal structures. Methods and means of non-destructive testing of industrial equipment: materials of the 7th scientific-practical conference (Ivano-Frankivsk, November 19-20, 2019). Ivano-Frankivsk: IIT, IFNTUNG, 23-25.

4. Finally, A. W. (2019). Ultrasonic quality control of welded joints Methods and means of non-destructive testing of industrial equipment: materials of the 7th scientific-practical conference (Ivano-Frankivsk, November 19-20, 2019). Ivano-Frankivsk: IIT, IFNTUNG, 87-88.

5. Radko, O.V., Kremeshny, O.I., Skuratovsky, A.K., Golembievsky, G.G. (2013). Methods of non-destructive testing of structures made of composite materials. Weapons systems and military equipment, 3 (35), 111.

6. Zaporozhets, A.O., Sverdlova, A.D. (2017). Analysis of methods for diagnosing thermal power facilities. Science-intensive technologies, 3 (35), 259-265.

7. Deineka, R. (2017). Magnetoconductive method of defectoscopy of ferromagnetic materials. Bulletin of the National University "Lviv Polytechnic". Series: Optimization of production processes and technical control in mechanical engineering and instrument making. Lviv: Lviv Polytechnic Publishing House, 867, 60-63. 
8. Chernogor, L. F., Lazorenko, O. V., \& Potapov, A. A. (2012, September). Wavelet analysis of multi-fractal ultra-wideband processes in problems of geospace physics. In 2012 6th International Conference on Ultrawideband and Ultrashort Impulse Signals (pp. 249251). IEEE.

9. Sebko, VV, \& Zdorenko, VG (2019). Implementation of eddy current control method based on determining the components of the difference signal of a three-parameter converter with a tubular product. Bulletin of Kyiv National University of Technology and Design. Series: Technical Sciences, (1), 26-35.

10. Golik, O. V., \& Shchebeniuk, L. A. (2017). Statistical aspects of non-destructive testing of polyimide enamel insulation defects in production conditions. Electrical Engineering and Electromechanics, (1), 47-53.

11. Horlo, N.F. (2019). Accreditation of organizations performing non-destructive testing as a necessary condition for Ukrainian enterprises to access international markets for industrial goods and services. Mekhanika and machine-building, 1, 171-175. 